\title{
No MSH6 germline mutations in breast cancer families with colorectal and/or endometrial cancer
}

\author{
P Vahteristo, S Ojala, A Tamminen, J Tommiska, H Sammalkorpi, S Kiuru-Kuhlefelt, H Eerola, \\ L A Aaltonen, K Aittomäki, H Nevanlinna
}

J Med Genet 2005;42:e22 (http://www.jmedgenet.com/cgi/content/full/42/4/e22). doi: 10.1136/jmg.2004.022327

\begin{abstract}
Background: The genetic background in breast cancer families with colorectal and/or endometrial cancer is mostly unknown. The functional connection between MSH6 and the known breast cancer predisposition gene product BRCA1 suggests that the MSH6 gene may also play a role in breast cancer predisposition.

Methods: We analysed 38 breast cancer families with colorectal and/or endometrial cancer for germline mutations in MSH6.

Results: No disease associated mutations were detected among the breast cancer families. However, mutation analysis revealed a Glu995STOP mutation in an atypical HNPCC family. The same mutation was found in a patient with both breast and colorectal carcinoma in our previous study, and haplotype analysis confirmed a common ancestral origin. The Glu995STOP mutation was further examined in an extensive series of 245 colorectal and 142 breast carcinoma patients with a family history of breast, colorectal, and/or endometrial carcinoma, and in 268 healthy population controls, but none was found to carry the mutation.

Conclusions: Our results suggest that MSH6 may not be the underlying gene in breast cancer families with a history of colorectal and/or endometrial cancer. The Glu995STOP founder mutation is not a familial breast cancer predisposition allele and makes only a limited contribution to colorectal cancer burden in Finland.
\end{abstract}

\footnotetext{
I
} nherited mutations in DNA mismatch repair (MMR) genes cause susceptibility to hereditary non-polyposis colorectal cancer (HNPCC), an autosomal dominant cancer predisposition syndrome characterised by early onset colorectal cancer, and frequently showing extracolonic tumours such as cancers of the endometrium, stomach, ovaries, small bowel, ureter, and renal pelvis. ${ }^{1}$ The vast majority of the observed germline mutations in HNPCC families are in the MLHI ( $\sim 50 \%)$ and MSH2 ( 40\%) genes (www.insight-group.org; International Society for Gastrointestinal Hereditary Tumours). The first germline mutation in MSH6 was found in a patient with three colorectal tumours and a weak family history of gastrointestinal tumours, indicating atypical HNPCC. ${ }^{2}$ Further reports on families with germline MSH6 mutations have also shown different clinical features compared with traditional HNPCC phenotype, such as later age of cancer diagnosis, lower penetrance, and predominance of endometrial carcinomas. ${ }^{3-6}$ In a recent study by Hendriks et al, the cumulative risks at 70 years for MLH1, MSH2, and MSH6 mutation carriers were similar for all the HNPCC related tumours combined. ${ }^{7}$ For women, colorectal cancer risk was significantly lower and endometrial cancer risk significantly higher in MSH6 carriers compared with MLHI and MSH2 carriers. $^{7}$ In contrast to $M L H 1$ and $M S H 2$ mutation carriers, whose colorectal and endometrial tumours very often exhibit high microsatellite instability (MSI-H), ${ }^{8-10}$ tumours from MSH6 carriers more frequently show a lower degree of MSI (MSI-L) or are microsatellite stable (MSS). ${ }^{511} 12$ In breast cancer, MSI has been observed in some sporadic ${ }^{13-16}$ and familial ${ }^{17}$ breast tumours and in a few breast tumours of known HNPCC patients. ${ }^{18} 19$

The genetic background in breast cancer families with colorectal and/or endometrial cancer is mostly unknown. Studies on breast cancer risk in HNPCC have also given conflicting results. ${ }^{18-22}$ For example, a statistically significant over-representation of breast cancer was observed in $\mathrm{MLHI}$ mutation positive families and in families with no detectable MLH1 or MSH2 mutations, ${ }^{23}$ but the finding was not confirmed in another study. ${ }^{24}$ The aforementioned studies have mainly focused on classic HNPCC families, and thus the possible effect of MSH6 may have been overlooked. The MSH6 protein, along with MLHI and MSH2, is part of the so called BRCAl associated genome surveillance complex (BASC), which is suggested to serve as a sensor for DNA damage. ${ }^{25}$ This large protein complex is comprised of BRCAl associated DNA repair proteins, all of which possess the ability to bind abnormal DNA structures. Protein-protein interaction between BRCAl, the protein product of a known breast cancer predisposing gene, and the proteins associated with it may indicate that they function in the same DNA damage response pathway. ${ }^{25}$ Reduced MSH6 mRNA expression has also been observed in breast tumour derived cell lines. ${ }^{26}$ In our previous study, we found a germline MSH6 mutation in a patient with both breast and colorectal carcinoma, ${ }^{27}$ and a similar patient has been reported by Plaschke et al. ${ }^{28}$ In addition, Hendriks et al have reported on an MSH6 mutation positive breast cancer patient whose tumour showed an MSI-H phenotype and no MSH6 expression. ${ }^{7}$ In this study, our aim was to evaluate the role of MSH6 in breast cancer predisposition by analysing 38 breast cancer families with family history of colorectal and/or endometrial cancer for germline MSH6 mutations. In addition, a previously reported putatively breast cancer associated Finnish MSH6 mutation was evaluated in an extensive set of breast and colorectal cancer cases.

\section{PATIENTS AND METHODS}

\section{Breast cancer families}

In the study, 38 families originally ascertained from a group of breast cancer patients at the Departments of Oncology or Clinical Genetics, Helsinki University Central Hospital, Finland, fulfilled the following clinical criteria for this study: (a) at least one breast cancer case, and ( $b$ ) either endometrial or colorectal carcinoma patient, and (c) additional endometrial or colorectal carcinoma patient or family history of at least one of the following tumours: stomach, small intestine, bile duct, pancreatic, ovarian, kidney, or ureter carcinoma, 
adenocarcinoma of the cervix, or malignant brain tumour. Families were classified according to the presence of breast, colorectal, and endometrial cancer cases in the family (table 1). One family fulfilled the Amsterdam criteria, and 10 families the Revised Bethesda Guidelines for HNPCC. ${ }^{29}{ }^{30}$ No BRCA1 or BRCA2 mutations were detected in any of the families, and the presence of the three MLHI founder mutations that account for the large majority of all MMR mutations in Finland were excluded. For each family, the index patient and, when available, relatives with endometrial or colorectal carcinoma were analysed for germline MSH6 mutations, with the total of 42 samples in the analysis.

\section{Breast and colorectal carcinoma patients with family history of cancer}

The observed MSH6 founder mutation was analysed in 142 breast carcinoma patients who themselves or whose first degree relative had colorectal $(\mathrm{n}=70)$ or endometrial $(\mathrm{n}=81)$ carcinoma, and 245 colorectal carcinoma patients who themselves or whose first degree relative had additional colorectal carcinoma $(n=143)$, breast $(n=86)$, or endometrial $(n=23)$ carcinoma. The 142 breast cancer patients belong to the cohorts of 889 unselected $^{31}$ (also unpublished data) and 710 familial breast cancer cases ${ }^{32-34}$ (also unpublished data). None of the 142 families fulfilled the Amsterdam criteria, while 15 families fulfilled the Revised Bethesda Guidelines for HNPCC. ${ }^{29}{ }^{30}$ Colorectal cancer patient samples were selected from a population based series of 1042 consecutive colorectal cancer cases previously described. ${ }^{35} 36$

MSI was determined using a polyA marker BAT26, a robust marker for high level MSI detection; 24 of the 245 samples were MSI positive, and 14/245 were shown to harbour a germline mutation in either $M L H 1$ or $M_{S H} 2^{35}{ }^{36}$ (also unpublished data). Three of the 245 families fulfilled the Amsterdam criteria and 83 families fulfilled the Revised Bethesda Guidelines for HNPCC..$^{29}$ To evaluate the frequency of the observed MSH6 mutation in population controls, blood samples from 268 healthy anonymous blood donors were studied.

All specimens were collected and analysed with informed consent and under protocols approved by ethics committees of the Departments of Obstetrics and Gynecology, and Oncology, Helsinki University Central Hospital, Finland, and the Ministry of Social Affairs and Health in Finland.

Table 1 Family history of breast, colorectal, and endometrial cancer among the families studied

\begin{tabular}{ll}
\hline $\begin{array}{l}\text { Breast, colorectal, and endometrial cancer patients in the } \\
\text { families }\end{array}$ & $\begin{array}{l}\text { No. of } \\
\text { families }\end{array}$ \\
\hline 3 breast cancer patients & 28 \\
with at least one colorectal cancer patient in a family & 16 \\
with at least one endometrial cancer patient in a family & 6 \\
with at least one colorectal and one endometrial cancer & 6 \\
patient in a family & 7 \\
2 breast cancer patients & 4 \\
with at least one colorectal cancer patient in a family & 2 \\
with at least one endometrial cancer patient in a family & 2 \\
with at least one colorectal and one endometrial cancer & 1 \\
patient in a family & 3 \\
1 breast cancer patient & 2 \\
with at least one colorectal and one endometrial cancer & \\
patient in a family & 1 \\
with several primary tumours (at least breast and & \\
colorectal/endometrial) & 38 \\
\hline Total &
\end{tabular}

\section{Mutation analysis}

All 10 exons and exon-intron boundaries were screened for germline MSH6 mutations by conformation sensitive gel electrophoresis (CSGE), with modifications previously described. ${ }^{27}$ Briefly, genomic DNA was amplified by PCR, with one of the primers being end labelled with $\gamma-{ }^{33} \mathrm{P}$-dATP (PerkinElmer Life Sciences, Boston, MA, USA) using T4 polynucleotide kinase (New England Biolabs, Beverly, MA, USA). PCR products were then denatured for 10 minutes at $95^{\circ} \mathrm{C}$, and heteroduplexes were allowed to form by letting the samples slowly cool to room temperature. Samples were run on mildly denaturing CSGE gels ( $10 \%$ acrylamide, $10 \%$ ethylene glycol, $15 \%$ formamide) either at $35 \mathrm{~W}$ for 3-4 hours or at $3 \mathrm{~W}$ overnight. All samples with an abnormal band shift were reamplified and sequenced by direct sequencing using BigDye Terminator Cycle Sequencing kit (version 3.1) and ABI 310 automated sequencer (Applied Biosystems, Foster City, CA, USA).

\section{Haplotype analysis}

Haplotype analysis was performed in order to evaluate the possible common ancestry of the observed MSH6 mutation. The polymorphic microsatellite markers used were: D2S119, D2S2298, D2S2174, D2S2240, and D2S2378. The analysis was done by end labelling one of the primers with $\gamma-{ }^{33} \mathrm{P}$-dATP (PerkinElmer Life Sciences) and separating the denatured PCR products in a mildly denaturing $10 \%$ polyacrylamide gel.

\section{RESULTS AND DISCUSSION}

Identification of mismatches that have occurred during replication or recombination of homologous but non-identical DNA sequences is accomplished by two heterodimeric complexes, MSH $\alpha$ and MSH $\beta$. The former, comprising of MSH2 and MSH6, is primarily responsible for the recognition of single nucleotide mismatches and small insertion/deletion loops, ${ }^{37-39}$ whereas the latter, with MSH2 and MSH3, preferentially recognises insertion/deletion loops. ${ }^{39} 40$ The partial functional redundancy of the two complexes may explain both the rarity of germline MSH6 mutations in HNPCC and the atypical HNPCC phenotype common to families with such mutations. Interestingly, in contrast to MSH6, where several disease causing germline mutations have been identified in HNPCC and atypical HNPCC, such mutations are thus far lacking for MSH3.

The role of germline mutations in MMR genes in breast cancer predisposition has remained controversial, though major contribution appears unlikely. Results from most epidemiological studies suggest that breast tumours are not associated with HNPCC syndrome, ${ }^{122} 24$ although Scott et al ${ }^{23}$ reported a 15 fold excess in lifetime breast cancer risk among MLH1 mutation carriers. As the aforementioned studies have mostly concentrated on classic HNPCC families with either $M L H 1, M S H 2$, or unknown mutation status, it may be that the effect of MSH6 has been overlooked as germline mutations in MSH6 predispose mainly to atypical HNPCC. We ${ }^{27}$ and others $^{28}$ have also reported on MSH6 mutation carriers with both breast and colorectal carcinoma. Colorectal cancer is a common feature in breast cancer families, and 16\% of Finnish breast cancer families include also colorectal cancer patients. ${ }^{41}$ The underlying predisposition gene in such families is unknown. The aim of this study was to formally analyse the role of MSH6 in breast cancer families who also have endometrial and/or colorectal cancer patients.

Altogether, eight germline alterations in the coding and seven in the non-coding region were observed in the 38 families (table 2). Six of the coding variants were silent substitutions, five of which have been reported as polymorphisms (www.insight-group.org; International Society for Gastrointestinal Hereditary Tumours). In addition, both 
Table 2 Germline MSH6 alterations in breast cancer families

\begin{tabular}{|c|c|c|c|c|}
\hline Location & $\begin{array}{l}\text { Nucleotide } \\
\text { change }\end{array}$ & $\begin{array}{l}\text { Effect } \\
\text { on protein }\end{array}$ & $\begin{array}{l}\text { Families } \\
\text { with the } \\
\text { variant }\end{array}$ & $\begin{array}{l}\text { Variant } \\
\text { previously } \\
\text { described } \\
\text { (reference } \\
\text { no.) }\end{array}$ \\
\hline Exon 1 & $116 \mathrm{G} \rightarrow \mathrm{A}$ & Gly39Glu & 4 & 44243 \\
\hline Exon 1 & $186 \mathrm{C} \rightarrow \mathrm{A}$ & Arg62Arg & 15 & 44243 \\
\hline Exon 2 & $276 \mathrm{~A} \rightarrow \mathrm{G}$ & Pro92Pro & 9 & 44243 \\
\hline Exon 3 & $540 \mathrm{~T} \rightarrow \mathrm{C}$ & Asp180Asp & 15 & 4543 \\
\hline Intron 3 & $628-56 \mathrm{C} \rightarrow \mathrm{T}$ & & 9* & 443 \\
\hline Exon 4 & $642 \mathrm{C} \rightarrow \mathrm{T}$ & Tyr214Tyr & $8^{*}$ & 4543 \\
\hline Exon 4 & $1186 C \rightarrow G$ & Leu396Val & 2 & 45 \\
\hline Exon 4 & $1875 \mathrm{C} \rightarrow \mathrm{T}$ & Ser625Ser & 1 & \\
\hline Exon 5 & $3306 \mathrm{~T} \rightarrow \mathrm{A}$ & Thr1 102Thr & 1 & 4 \\
\hline Intron 5 & $3438+14 \mathrm{~A} \rightarrow \mathrm{T}$ & & 20 & 443 \\
\hline Intron 6 & 3557-18delT/insT & & $\dagger$ & \\
\hline Intron 7 & $3646+29$ delCTAT & & $35^{*}$ & \\
\hline Intron 7 & 3647-54 del17 & & 9* & 443 \\
\hline Intron 9 & 4002-27delT & & $\ddagger$ & \\
\hline 3'UTR & $4083+49 G \rightarrow C$ & & 1 & \\
\hline
\end{tabular}

*Also homozygotes for the rare allele; †microsatellite with 12-14xT (12) $13, \mathrm{n}=25 ; 13 / 14, \mathrm{n}=13$ ); ‡microsatellite with 17-18xT, all samples heterozygotes $(17 / 18)$.

missense changes (Gly39Glu and Leu396Val) have been previously classified as polymorphisms, and functional analysis of the latter has shown that a plasmid with the Leu396Val gene is able to complement the mismatch repair defect of an msh 3 msh6 double mutant strain. ${ }^{4}$ Intronic variants observed in this study were common and located outside the conserved splice sites, suggesting that they may not have functional significance. It is possible that some mutations may have been missed in this study, as the CSGE method is known to be less than $100 \%$ sensitive and we did not look for large genomic rearrangements. In addition, the sample size in the mutation screening is quite small. Despite these limitations, the absence of disease associated mutations suggests that MSH6 germline mutations are not, or only rarely, the cause of breast cancer in families with family history of colorectal and/or endometrial cancer.

In the course of this study, a complete mutation analysis of an additional family in which the colorectal tumour showed no MSH6 expression in immunohistochemical analysis revealed the same Glu995STOP mutation that was seen in our previous study in a patient with both breast and colorectal carcinoma. ${ }^{27}$ Glu995STOP is a protein truncating mutation deleting 365 amino acids from the $\mathrm{C}$ terminal end of the protein, including domains that are conserved in many MutS homologues and participate in, for example, DNA binding, ATPase activity, and protein dimerisation ${ }^{44} 45$ (www.ensembl.org/homo sapiens/). The mutation positive families that are not known to be related originate from the same geographical region of Southern Finland, and haplotype analysis confirmed the common ancestral origin of the mutation (fig 1). Both families show atypical HNPCC, with predominance of endometrial carcinoma. Both families do, however, fulfil the revised Bethesda Guidelines for $\mathrm{HNPCC}^{30}$; family 5130 with the presence of a colorectal cancer patient diagnosed before 50 years of age, and family 2342 with the presence of both colorectal and endometrial carcinoma in the same patient.

Recurrent founder mutations provide another approach to evaluate the presence of susceptibility gene mutations in more extensive sets of patients and families, and have been useful in cancer susceptibility gene studies in Finland. ${ }^{31} 3536$ To further analyse the importance of this particular Glu995STOP mutation among Finnish breast and colorectal carcinoma patients with family history of cancer, we studied its frequency in 245 colorectal cancer patients who themselves or whose first degree relative had been diagnosed with additional colorectal carcinoma or breast or endometrial carcinoma, and in 142 breast cancer patients who themselves or whose first degree relative had colorectal or endometrial carcinoma. Of these 387 patients, 72 (18.6\%; 26 colorectal and 46 breast cancer patients) were from the same geographical region as the mutation carriers. None was found to carry the mutation. The mutation was also absent in 268 anonymous Finnish blood donors. This suggests that the Glu995STOP is a new Finnish MSH6 founder mutation that may have some relevance in a geographically restricted area, but its contribution to colorectal cancer burden is limited. The results also indicate that the Glu995STOP is not a familial breast cancer predisposition allele.

In the other MSH6 positive family (5130), a CHEK2 1100delC mutation has also been identified. ${ }^{27}$ Both mutations were found in the index patient diagnosed with both breast and colorectal carcinoma at the age of 34 years, and in her mother, who had been diagnosed with benign meningioma. As the CHEK2 1100delC is now known to act as a low penetrance breast cancer allele ${ }^{46}{ }^{47}$ and MSH6 is known to predispose to colorectal cancer, it appears likely that the breast carcinoma from the index patient was caused by the CHEK2 mutation and the colorectal tumour by the MSH6

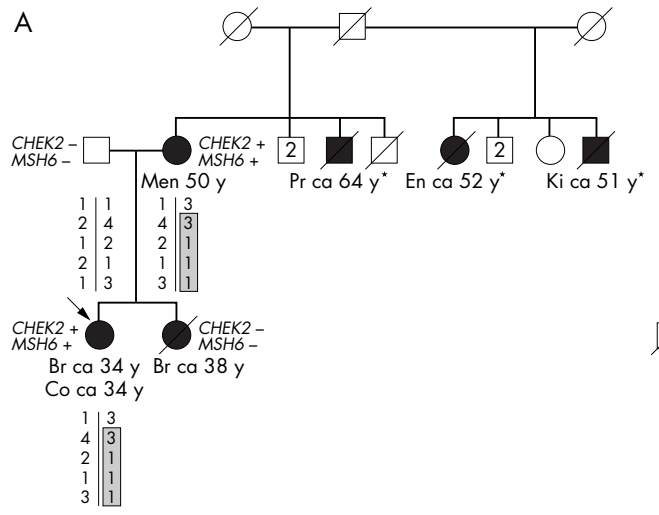

B

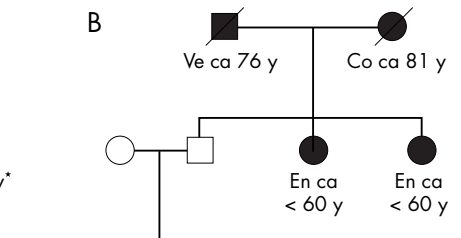

Figure 1 Pedigrees of the families with the germline MSH6 Glu995STOP mutation: (A) 5130, (B) 2342.

Probands are indicated by an arrow. Tumour site(s) and age at diagnosis are indicated: $\mathrm{Br}$, breast; $\mathrm{Co}$, colon; $\mathrm{En}$, endometrium; Ki, kidney; Men, meningioma; Pr, prostate; $\mathrm{Ve}$, ventricle. ${ }^{*}$ Diagnosis could not be verified from medical documents; the age presented is the at death. Haplotypes are shown beneath the individuals, with the shadowed haplotype referring to a shared disease haplotype. 
mutation. This is further supported by the MSH6 immunohistochemical staining and MSI analyses on the colorectal and breast tumours: while the colorectal tumour shows no MSH6 expression and exhibits MSI-H, the breast tumour is MSS and shows only slightly reduced MSH6 expression as compared with adjacent normal tissue. The index patients' sister was diagnosed with breast cancer at the age of 38 years, but she was not found to carry either of the mutations and her tumour is most likely sporadic. Alternatively, there may also be a currently unknown genetic factor or an undetected BRCAI/2 mutation underlying the early onset breast cancer cases in this family. In another MSH6 mutation carrier affected with both colorectal and breast carcinoma, the breast tumour did not exhibit MSI or loss of MSH6 expression, and it was suggested that also that breast tumour is most likely not due to mismatch repair deficiency. ${ }^{28}$ Despite the MSH6 positive breast cancer patient whose tumour exhibits MSI-H and loss of MSH6 expression, ${ }^{7}$ in most published cases the mutation status of the breast cancer patient is unknown or the patient with breast cancer has not been a mutation carrier. ${ }^{45} 11124849$ Therefore, many breast cancer cases among MSH6 families may be sporadic or due to other breast cancer predisposition alleles.

Both breast and colorectal carcinomas are common tumours that often occur together in families. This coexistence may be due to chance clustering of two common cancers, but there may also be genetic factors that predispose to both cancer types..$^{50}$ Mutations in LKBI that predispose to Peutz-Jeghers syndrome have been associated with an increased risk for both breast and colorectal cancer. ${ }^{51}$ Elevated colorectal cancer risk has also been reported for BRCA1 and BRCA2 mutation carriers, although the results have been inconsistent. ${ }^{52-55}$ In addition, the studies on whether the breast cancer risk is increased among HNPCC families have given contradictory results. ${ }^{18-22} 24$ Altogether, germline mutations in all of these genes may explain only a small fraction of families with both of these tumour types. The presence of families with a strong family history of both breast and colorectal carcinomas and no mutations in the known predisposition genes have led to the suggestion that there may be a novel gene(s) associated, when mutated, to an increased risk for both cancer types. ${ }^{50}$ Recently, the CHEK2 l100delC mutation was found to be associated with families with both breast and colorectal cancer, and was suggested to underlie the hereditary breast and colorectal cancer syndrome HBCC. ${ }^{56}$ However, the observation was not confirmed in a study by Kilpivaara et al. ${ }^{41}$ Furthermore, no statistically significant increase in the 1100delC mutation frequency has been observed either in familial or in sporadic colorectal cancer ${ }^{41}{ }^{56}$ or in patients with multiple adenomas, ${ }^{57}$ suggesting that its effect on colorectal cancer is very low or nonexistent.

The absence of germline MSH6 mutations in our set of breast cancer families and patients studied here do not exclude the possibility that MSH6 mutations may be associated with an increased breast cancer risk in the context of MSH6 mutation carrier HNPCC families. However, our results suggest that $\mathrm{MSH} 6$ is not a breast cancer predisposition gene that would manifest itself in breast cancer patients and families with the family history of colorectal and/or endometrial cancer. Other breast/colorectal cancer susceptibility genes are likely to be the cause in such families.

\section{ACKNOWLEDGEMENTS}

We wish to thank Dr C Blomqvist and research nurses M Merikivi and N Puolakka for their help with the patient data and samples. This study was supported by Helsinki University Central Hospital Research Fund, Sigrid Juselius Foundation, Finnish Cancer Society, Academy of Finland, Maud Kuistila Foundation, and the Research and Science Foundation of Farmos.

\section{Authors' affiliations}

P Vahteristo, S Ojala, A Tamminen, J Tommiska, H Eerola,

H Nevanlinna, Department of Obstetrics and Gynecology, Helsinki University Central Hospital, Helsinki, Finland

H Sammalkorpi, S Kiuru-Kuhlefelt, L A Aaltonen, K Aittomäki,

Department of Medical Genetics, Helsinki University, Helsinki, Finland

H Eerola, Department of Oncology, Helsinki University Central Hospital, Helsinki, Finland

S Kiuru-Kuhlefelt, K Aittomäki, Department of Medical Genetics, Helsinki University Central Hospital, Helsinki, Finland

Competing interests: none declared

Correspondence to: Dr H Nevanlinna, Department of Obstetrics and Gynecology, Helsinki University Central Hospital, Biomedicum Helsinki, PO Box 700, FIN-00029 HUS, Finland; heli.nevanlinna@hus.fi

Received 5 May 2004

Revised version received 20 December 2004

Accepted 21 December 2004

\section{REFERENCES}

1 Watson P, Lynch HT. Extracolonic cancer in hereditary nonpolyposis colorectal cancer. Cancer 1993;71:677-85.

2 Akiyama Y, Sato H, Yamada T, Nagasaki H, Tsuchiya A, Abe R, Yuasa Y. Germ-line mutation of the hMSH6/GTBP gene in an atypical hereditary nonpolyposis colorectal cancer kindred. Cancer Res 1997;57:3920-3.

3 Miyaki M, Konishi M, Tanaka K, Kikuchi-Yanoshita R, Muraoka M, Yasuno M, Igari T, Koike M, Chiba M, Mori T. Germline mutation of MSH6 as the cause of hereditary nonpolyposis colorectal cancer. Nat Genet 1997;17:271-2.

4 Kolodner RD, Tytell JD, Schmeits JL, Kane MF, Gupta RD, Weger J, Wahlberg S, Fox EA, Peel D, Ziogas A, Garber JE, Syngal S, Anton-Culver H, Li FP. Germ-line msh6 mutations in colorectal cancer families. Cancer Res 1999:59:5068-74

5 Wijnen J, de Leeuw W, Vasen $\mathrm{H}$, van $\operatorname{der} \mathrm{Kliff} H$, Moller $\mathrm{P}$, Stormorken A, Meijers-Heijboer H, Lindhout D, Menko F, Vossen S, Moslein G, Tops C, Brocker-Vriends A, Wu Y, Hofstra R, Sijmons R, Cornelisse C, Morreau H, Fodde R. Familial endometrial cancer in female carriers of MSH6 germline mutations. Nat Genet 1999;23:142-4.

6 Wagner A, Hendriks Y, Meijers-Heijboer EJ, de Leeuw WJ, Morreau H, Hofstra R, Tops C, Bik E, Brocker-Vriends AH, van Der Meer C, Lindhout D, Vasen HF, Breuning MH, Cornelisse CJ, van Krimpen C, Niermeijer MF, Zwinderman AH, Wijnen J, Fodde R. Atypical HNPCC owing to MSH6 germline mutations: analysis of a large Dutch pedigree. J Med Genet 2001;38:318-22.

7 Hendriks YM, Wagner A, Morreau H, Menko F, Stormorken A, Quehenberger F, Sandkuiil L, Moller P, Genuardi M, Van Houwelingen H, Tops C, Van Puijenbroek M, Verkuijlen P, Kenter G, Van Mil A, MeijersHeijboer H, Tan GB, Breuning MH, Fodde R, Wijnen JT, Brocker-Vriends AH, Vasen $\mathrm{H}$. Cancer risk in hereditary nonpolyposis colorectal cancer due to MSH6 mutations: impact on counseling and surveillance. Gastroenterology 2004; 127:17-25.

8 Aaltonen LA, Peltomaki P, Leach FS, Sistonen P, Pylkkanen L, Mecklin JP, Jarvinen H, Powell SM, Jen J, Hamilton SR. Clues to the pathogenesis of familial colorectal cancer. Science 1993;260:812-16.

9 Ichikawa Y, Lemon SJ, Wang S, Franklin B, Watson P, Knezetic JA, Bewtra C, Lynch HT. Microsatellite instability and expression of $\mathrm{MLH} 1$ and MSH2 in normal and malignant endometrial and ovarian epithelium in hereditary nonpolyposis colorectal cancer family members. Cancer Genet Cytogenet 1999; 112:2-8.

10 de Leeuw WJ, Dierssen J, Vasen HF, Wijnen JT, Kenter GG, MeijersHeijboer H, Brocker-Vriends A, Stormorken A, Moller P, Menko F, Cornelisse CJ, Morreau H. Prediction of a mismatch repair gene defect by microsatellite instability and immunohistochemical analysis in endometrial tumours from HNPCC patients. J Pathol 2000;192:328-35.

11 Wu Y, Berends MJ, Mensink RG, Kempinga C, Sijmons RH, van Der Zee AG, Hollema H, Kleibeuker JH, Buys CH, Hofstra RM. Association of hereditary nonpolyposis colorectal cancer-related tumours displaying low microsatellite instability with MSH6 germline mutations. Am J Hum Genet 1999;65:1291-8.

12 Berends MJ, Wu Y, Sijmons RH, Mensink RG, van der Sluis T, Hordijk-Hos JM, de Vries EG, Hollema H, Karrenbeld A, Buys CH, van der Zee AG, Hofstra RM, Kleibeuker JH. Molecular and clinical characteristics of MSH6 variants: an analysis of 25 index carriers of a germline variant. Am J Hum Genet 2002;70:26-37.

13 Toyama T, Iwase H, Yamashita H, Iwata H, Yamashita T, Ito K, Hara Y, Suchi M, Kato T, Nakamura T, Kobayashi S. Microsatellite instability in sporadic human breast cancers. Int J Cancer 1996;68:447-51.

14 Tomita S, Deguchi S, Miyaguni T, Muto Y, Tamamoto T, Toda T. Analyses of microsatellite instability and the transforming growth factor-beta receptor type II gene mutation in sporadic breast cancer and their correlation with clinicopathological features. Breast Cancer Res Treat 1999;53:33-9.

15 Caldes T, Perez-Segura P, Tosar A, De La Hoya M, Diaz-Rubio E. Low frequency of microsatellite instability in sporadic breast cancer. Int J Oncol 2000;16:1235-42.

16 Halford SE, Sawyer EJ, Lambros MB, Gorman P, Macdonald ND, Talbot IC, Foulkes WD, Gillett CE, Barnes DM, Akslen LA, Lee K, Jacobs IJ, Hanby AM, 
Ganesan TS, Salvesen HB, Bodmer WF, Tomlinson IP, Roylance RR. MSI-low a real phenomenon which varies in frequency among cancer types. J Patho 2003;201:389-94.

17 Glebov OK, McKenzie KE, White CA, Sukumar S. Frequent p53 gene mutations and novel alleles in familial breast cancer. Cancer Res 1994;54:3703-9.

18 Risinger JI, Barrett JC, Watson P, Lynch HT, Boyd J. Molecular genetic evidence of the occurrence of breast cancer as an integral tumor in patients with the hereditary nonpolyposis colorectal carcinoma syndrome. Cancer 1996:77:1836-43.

19 Boyd J, Rhei E, Federici MG, Borgen PI, Watson P, Franklin B, Karr B, Lynch J, Lemon SJ, Lynch HT. Male breast cancer in the hereditary nonpolyposis colorectal cancer syndrome. Breast Cancer Res Treat 1999;53:87-91.

20 Itoh H, Houlston RS, Harocopos C, Slack J. Risk of cancer death in first-degree relatives of patients with hereditary non-polyposis cancer syndrome (Lynch type II): a study of 130 kindreds in the United Kingdom. Br J Surg 1990;77:1367-70.

21 Nelson CL, Sellers TA, Rich SS, Potter JD, McGovern PG, Kushi LH. Familial clustering of colon, breast, uterine, and ovarian cancers as assessed by family history. Genet Epidemiol 1993; 10:235-44.

22 Aarnio M, Sankila R, Pukkala E, Salovaara R, Aaltonen LA, de la Chapelle A, Peltomaki P, Mecklin JP, Jarvinen HJ. Cancer risk in mutation carriers of DNAmismatch-repair genes. Int J Cancer 1999;81:214-18.

23 Scott RJ, McPhillips M, Meldrum CJ, Fitzgerald PE, Adams K, Spigelman AD du Sart D, Tucker K, Kirk J. Hereditary nonpolyposis colorectal cancer in 95 families: differences and similarities between mutation-positive and mutation negative kindreds. Am J Hum Genet 2001;68:118-27.

24 Vasen HF, Morreau H, Nortier JW. Is breast cancer part of the tumor spectrum of hereditary nonpolyposis colorectal cancer? Am J Hum Genet $2001 ; 68: 1533-5$.

25 Wang Y, Cortez D, Yazdi P, Neff N, Elledge SJ, Qin J. BASC, a super complex of BRCA1-associated proteins involved in the recognition and repair of aberrant DNA structures. Genes Dev 2000;14:927-39.

26 Balogh GA, Russo IH, Russo J. Mutations in mismatch repair genes are involved in the neoplastic transformation of human breast epithelial cells. Int J Oncol 2003;23:411-19.

27 Vahteristo P, Tamminen A, Karvinen P, Eerola H, Eklund C, Aaltonen LA, Blomgvist C, Aittomaki K, Nevanlinna H. p53, CHK2, and CHK1 genes in Finnish families with Li-Fraumeni syndrome: further evidence of CHK2 in inherited cancer predisposition. Cancer Res 2001;61:5718-22.

28 Plaschke J, Kruger S, Pistorius S, Theissig F, Saeger HD, Schackert HK Involvement of hMSH6 in the development of hereditary and sporadic colorectal cancer revealed by immunostaining is based on germline mutations, but rarely on somatic inactivation. Int J Cancer 2002;97:643-8

29 Vasen HF, Mecklin JP, Khan PM, Lynch HT. The International Collaborative Group on Hereditary Non-Polyposis Colorectal Cancer (ICG-HNPCC). Dis Colon Rectum 1991;34:424-5.

30 Umar A, Boland CR, Terdiman JP, Syngal S, de la Chapelle A, Ruschoff J, Fishel R, Lindor NM, Burgart $U$, Hamelin R, Hamilton SR, Hiatt RA, Jass J, Lindblom A, Lynch HT, Peltomaki P, Ramsey SD, Rodriguez-Bigas MA, Vasen HF, Hawk ET, Barrett JC, Freedman AN, Srivastava S. Revised Bethesda Guidelines for hereditary nonpolyposis colorectal cancer (Lynch syndrome) and microsatellite instability. J Natl Cancer Inst 2004;96:261-8.

31 Syrjakoski K, Vahteristo P, Eerola H, Tamminen A, Kivinummi K, Sarantaus L Holli K, Blomqvist C, Kallioniemi OP, Kainu T, Nevanlinna HPopulation-based study of BRCA1 and BRCA2 mutations in 1035 unselected Finnish breast cancer patients. J Natl Cancer Inst 2000;92:1529-31.

32 Vahteristo P, Eerola H, Tamminen A, Blomgvist C, Nevanlinna H. A probability model for predicting BRCA1 and BRCA2 mutations in breast and breast-ovarian cancer families. Br J Cancer 2001;84:704-8.

33 Vehmanen P, Friedman LS, Eerola H, Sarantaus L, Pyrhonen S, Ponder BA, Muhonen T, Nevanlinna $\mathrm{H}$. A low proportion of BRCA2 mutations in Finnish breast cancer families. Am J Hum Genet 1997;60:1050-8.

34 Vehmanen P, Friedman LS, Eerola H, McClure M, Ward B, Sarantaus L, Kainu T, Syriakoski K, Pyrhonen S, Kallioniemi OP, Muhonen T, Luce M, Frank TS, Nevanlinna H. Low proportion of BRCA1 and BRCA2 mutations in Finnish breast cancer families: evidence for additional susceptibility genes. Hum Mol Genet 1997;6:2309-15.

35 Aaltonen LA, Salovaara R, Kristo P, Canzian F, Hemminki A, Peltomaki P, Chadwick RB, Kaariainen $H$, Eskelinen $M$, Jarvinen $H$, Mecklin JP, de la Chapelle A. Incidence of hereditary nonpolyposis colorectal cancer and the feasibility of molecular screening for the disease. N Engl J Med 1998;338:1481-7.

36 Salovaara R, Loukola A, Kristo $P$, Kaariainen $H$, Ahtola $H$, Eskelinen $M$, Harkonen N, Julkunen R, Kangas E, Ojala S, Tulikoura J, Valkamo E, Jarvinen H, Mecklin JP, Aaltonen LA, de la Chapelle A. Population-based molecular detection of hereditary nonpolyposis colorectal cancer. J Clin Oncol 2000; 18:2193-200

37 Drummond JT, Li GM, Longley MJ, Modrich P. Isolation of an hMSH2-pl 60 heterodimer that restores DNA mismatch repair to tumor cells. Science 1995;268:1909-12.
38 Palombo F, Gallinari P, laccarino I, Lettieri T, Hughes M, D'Arrigo A, Truong O, Hsuan JJ, Jiricny J. GTBP, a 160-kilodalton protein essential for mismatch-binding activity in human cells. Science 1995;268:1912-14

39 Acharya S, Wilson T, Gradia S, Kane MF, Guerrette S, Marsischky GT, Kolodner R, Fishel R. hMSH2 forms specific mispair-binding complexes with hMSH3 and hMSH6. Proc Nat Acad Sci USA 1996;93:13629-34.

40 Palombo F, laccarino I, Nakajima E, Ikejima M, Shimada T, Jiricny J. hMutSbeta, a heterodimer of hMSH2 and hMSH3, binds to insertion/deletion loops in DNA. Curr Biol 1996;6:1181-4.

41 Kilpivaara O, Laiho P, Aaltonen LA, Nevanlinna H. CHEK2 1100delC and colorectal cancer. J Med Genet 2003;40:e110

42 Nicolaides NC, Palombo F, Kinzler KW, Vogelstein B, Jiricny J. Molecular cloning of the N-terminus of GTBP. Genomics 1996:31:395-7.

43 Plaschke J, Kruppa C, Tischler R, Bocker T, Pistorius S, Dralle H, Ruschoff J, Saeger HD, Fishel R, Schackert HK. Sequence analysis of the mismatch repair gene hMSH6 in the germline of patients with familial and sporadic colorectal cancer. Int J Cancer 2000:85:606-13.

44 Lamers MH, Perrakis A, Enzlin JH, Winterwerp HH, de Wind N, Sixma TK. The crystal structure of DNA mismatch repair protein MutS binding to a G X T mismatch. Nature 2000;407:711-17.

45 Obmolova G, Ban C, Hsieh P, Yang W. Crystal structures of mismatch repair protein MutS and its complex with a substrate DNA. Nature 2000;407:703-10.

46 Meijers-Heijboer $H$, van den Ouweland A, Klijn J, Wasielewski M, de Snoo A, Oldenburg R, Hollestelle A, Houben M, Crepin E, van Veghel-Plandsoen M, Elstrodt F, van Duijn C, Bartels C, Meijers C, Schutte M, McGuffog L, Thompson D, Easton D, Sodha N, Seal S, Barfoot R, Mangion J, ChangClaude J, Eccles D, Eeles R, Evans DG, Houlston R, Murday V, Narod S, Peretz T, Peto J, Phelan C, Zhang HX, Szabo C, Devilee P, Goldgar D, Futreal PA, Nathanson KL, Weber B, Rahman N, Stratton MR, CHEK2-Breast Cancer Consortium. Low-penetrance susceptibility to breast cancer due to CHEK2(*)1 100delC in noncarriers of BRCA1 or BRCA2 mutations. Nat Genet 2002;31:55-9.

47 Vahteristo P, Bartkova J, Eerola H, Syrjakoski K, Ojala S, Kilpivaara O, Tamminen A, Kononen J, Aittomaki K, Heikkila P, Holli K, Blomqvist C, Bartek J, Kallioniemi OP, Nevanlinna H. A CHEK2 genetic variant contributing to a substantial fraction of familial breast cancer. Am J Hum Genet 2002;71:432-8.

48 Huang J, Kuismanen SA, Liu T, Chadwick RB, Johnson CK, Stevens MW Richards SK, Meek JE, Gao X, Wright FA, Mecklin JP, Jarvinen HJ, Gronberg H, Bisgaard ML, Lindblom A, Peltomaki P. MSH6 and MSH3 are rarely involved in genetic predisposition to nonpolypotic colon cancer. Cancer Res 2001;61:1619-23.

49 Plaschke J, Kruger S, Dietmaier W, Gebert J, Sutter C, Mangold E, Pagenstecher C, Holinski-Feder E, Śchulmann K, Moslein G, Ruschoff J, Engel C, Evans G, Schackert HK, German HNPCC Consortium. Eight novel $\mathrm{MSH} 6$ germline mutations in patients with familial and nonfamilial colorectal cancer selected by loss of protein expression in tumor tissue. Hum Mutat 2004; 23:285.

50 Lipton L, Thomas HJ, Eeles RA, Houlston RS, Longmuir M, Davison R, Hodgson SV, Murday VA, Norbury CG, Taylor C, Tomlinson IP. Apparent Mendelian inheritance of breast and colorectal cancer: chance, genetic heterogeneity or a new gene? Fam Cancer 2001;1:189-95.

51 Giardiello FM, Brensinger JD, Tersmette AC, Goodman SN, Petersen GM, Booker SV, Cruz-Correa M, Offerhaus JA. Very high risk of cancer in familial Peutz-Jeghers syndrome. Gastroenterology 2000; 1 19:1447-53.

52 Ford D, Easton DF, Stratton M, Narod S, Goldgar D, Devilee P, Bishop DT, Weber B, Lenoir G, Chang-Claude J, Sobol H, Teare MD, Struewing J, Arason A, Scherneck S, Peto J, Rebbeck TR, Tonin P, Neuhausen S, Barkardottir R, Eyfjord J, Lynch H, Ponder BA, Gayther SA, ZeladaHedman M. Risks of cancer in BRCA1-mutation carriers. Breast Cancer Linkage Consortium. Lancet 1994;343:692-5.

53 Cancer risks in BRCA2 mutation carriers. The Breast Cancer Linkage Consortium. J Natl Cancer Inst 1999;91:1310-16.

54 Risch HA, McLaughlin JR, Cole DE, Rosen B, Bradley L, Kwan E, Jack E, Vesprini DJ, Kuperstein G, Abrahamson JL, Fan I, Wong B, Narod SA Prevalence and penetrance of germline BRCA1 and BRCA2 mutations in a population series of 649 women with ovarian cancer. Am J Hum Genet 2001;68:700-10

55 Thompson D, Easton DF. Cancer Incidence in BRCA1 mutation carriers. J Natl Cancer Inst 2002;94:1358-65.

56 Meijers-Heijboer $\mathrm{H}$, Wijnen J, Vasen $\mathrm{H}$, Wasielewski M, Wagner $\mathrm{A}$, Hollestelle A, Elstrodt F, van den Bos R, de Snoo A, Fat GT, Brekelmans C, Jagmohan $S$, Franken $P$, Verkuiilen $P$, van den Ouweland $A$, Chapman $P$, Tops C, Moslein G, Burn J, Lynch H, Kliin J, Fodde R, Schutte M. The CHEK2 1100 delC mutation identifies families with a hereditary breast and colorectal cancer phenotype. Am J Hum Genet 2003;72:1308-14.

57 Lipton L, Fleischmann C, Sieber OM, Thomas HJ, Hodgson SV, Tomlinson IP, Houlston RS. Contribution of the CHEK2 1100 delC variant to risk of multiple colorectal adenoma and carcinoma. Cancer Lett 2003;200:149-52. 